\title{
Teachers' Difficulties and Strategies in Developing Narrative Texts as Learning Materials for Young Adolescent Regarding Theme System
}

\author{
Sri Setyarini, Fanissa Narita \\ Universitas Pendidikan Indonesia \\ fanissa.narita22@gmail.com
}

\begin{abstract}
This study entitled Teachers' Difficulties and Strategies in Developing Narrative Texts as Learning Materials for Young Adolescent aims to, 1) find out how the English teachers developed Narrative texts regarding to Theme system;2) identify what difficulties faced by the teacher in developing the texts; 3) discover strategies to overcome his difficulties. A descriptive qualitative method was employed as a research design focusing on a case study since one English teacher of young adolescent was recruited as the participant in this research. Data were collected through document analysis in the form of Narrative texts composed by the teacher and interview with the teacher. The collected data were analyzed based on Systemic Functional Linguistics to find out the Theme and Thematic progression patterns of the text. Meanwhile, the result of the interview was interpreted referring to the information about teacher's language awareness which influenced pedagogy. Based on the findings from document analysis, it revealed that the texts already fulfilled the Theme system which was indicated from the Theme choices and Thematic progression patterns. However, some difficulties were found due to teacher's lack of knowledge about Theme system analysis. Therefore, the teacher learned to understand well Theme system analysis to overcome the difficulties.
\end{abstract}

Key Terms: Teachers' Understanding and difficulties, Theme system, Thematic Progression patterns, Systemic Functional Linguistics

\section{INTRODUCTION}

Process of understanding text will run if the reader can catch the writer's message expressing the idea of writing, opinion, knowledge, fact, etc. However, some difficulties to understand the text are not only faced by the students but also by the teachers. As Brown (2001) and Gerrot (2000) have underlined that the current practice of selecting texts for students is far from adequate. According to them (Brown, 2001; Gerot, 2000) the idiosyncrasies of written language is a reason for certain reading difficulties experienced by the readers in reading test. Besides, there is a considerable body of research that attests to the inadequacy of teachers' grammatical knowledge. Regarding this, one aspect that should be taken into account in constructing the text is text's coherence. This aspect largely influences the process of reading comprehension in the reader's mind. Text's coherence facilities and enables reader to comprehend the text better, thought the topic is unfamiliar. Jing (2016) also said that Reader- Based coherence at global level-by requisite of consistent ideas- helps readers understand the development of ideas, concepts, or arguments, which coincides with the information structure composed. On the other hand, Systemic Functional Linguistics (SFL) has provided a tool for analyzing text's coherence. The connection and the development of ideas in the text can be traced by Theme system and Thematic progression pattern. As stated by Thompson (2014) that thematic organization is "a major aspect of how the message of text is delivered in a way which makes Theme fit smoothly into unfolding language event" (p.145). Therefore, Theme and Rheme construction can be considered as a valuable instrument in Language education for both the teachers and students side. From teachers' view, it helps teachers in making material for learning process (McCabe-Hidalgo, 1998 as cited in Shieh \& Lin, 2011). Besides, Theme system analysis also benefits readers from several aspects as suggested by Wang (2007). Firstly, the use of Theme system enables students to remember the most important information in the texts. Furthermore, drawing upon Thematic progression patterns is a very effective method for fast reading and keeps the students aware of the central information.

Concerning the explanation above, maintaining Theme and Thematic progression patterns in the texts is important especially for the teachers. In this case, teachers should be aware to the texts developed as learning materials for their students. Therefore, the teacher in that level (young adolescent) needs to understand how narrative text is arranged through considering Theme and Thematic progression patterns. By doing so, this study is expected to guide the teachers how to develop the text according to the appropriate Theme and Thematic progression patterns. Therefore, this study can facilitate the teacher to understand the way to develop narrative text appropriately according to Theme system as proposed in Systemic Functional Linguistics (Halliday \& Matthiessen, 2004). 


\section{METHODS}

This study employed a descriptive-qualitative method since this method attempted to provide the holistic description of complex phenomena (Fraenkel, Wallen \& Hyune, 2012). It was intended to investigate how the teacher developed Narrative texts by considering Theme and Thematic Progression patterns. In addition, it also identified what difficulties faced by the teacher in developing those texts as learning materials and strategies that the teacher took to overcome the problems. A case study was implemented since this research only focused on one English teacher of grade seventh as the participant of this study. There were two data resources, namely Narrative texts as documentation, while the interview with the teacher as the second data. The first data in the form of written texts were analyzed based on Systemic Functional Linguistics as proposed by Halliday and Matthiessen (2004) to find out Theme and Thematic Progression patterns found in the text. In contrast, the result of interview was used to identify difficulties faced by the teacher and strategies to cover them. These data were used to complete the data from the documentation.

\section{FINDINGS AND DISCUSSIONS}

According to data analysis, there were some points investigated in this study. Firstly how Theme and Thematic progression patterns were organized in the teacher's Narrative texts as learning materials; and what difficulties faced by the teacher in developing the texts and how to cover the teacher's problems. Dealt with Theme and Thematic Progression patterns the result showed that, the teacher mostly used a topical Theme namely marked and unmarked Theme to construct the Narratives. Firstly, the marked Theme was functioned to highlight particular points of time in the unfolding events (Emilia, 2014).The example of this theme was "once upon a time... found in orientation stage of Narrative text. Another example was found in evaluation stage as in "one day" which functioned to signal movement from one activity sequence to the next (Martin and Rose, 2008).In this case, the teacher used the theme to bridge the story from the conflict (complication) to the falling action (resolution). Meanwhile, the use of unmarked Theme was useful in order to introduce the characters since it roled as the subject of the clause. It also served to identify the topic under discussion (Emilia, 2005) such as in "they......, I.....,we....." construing the focus of the story on the character's journey. For example, the unmarked themes in orientation stage of the text 1 "the frogs saw" followed by Rheme which depicted frog's activity was used to introduce characters' overview since the purpose of orientation stage is to introduce the characters and give preliminary information about them (Eggins, 2004). The second dominant Theme applied in the texts was Textual Theme (around 30\%) filling several functions in the narratives. Firstly, it was used to link the clauses by creating logical connection and coherenceas awhole (Christie, 2005; Eggins,
2004; Lock, 1996). Moreover in Narrative,Textual Theme such as "so.... and ...then......" was also able to create a connection between the series of events in the story bringing it to the climax (Emilia, 2014). In addition, the circumstance adjuncts such as "after that, next, the next day" also appeared in the text intended to express continuities between actions and indicate that the story has shifted time frame and a new episode is about to start (Halliday \& Matthiessen, 2006, p. 9).Another TextualTheme was a contrast conjunction such as "but"essential to signal the complication or crisis point of the story (Butt et al., 2000). The least themeappeared was Interpersonal Theme (around 5\%) functioned to indicate the writer's or speaker's personal judgment on the meaning" (as cited in Emilia, 2014, p. 229). One of Interpersonal Themesin the text was "dreadfully" emerged in evaluation stage of the second text. The word presented characters' subjectivity as a response toward the conflict. It was appropriate with the characteristic of evaluation stage in Narrative which aims to make a reflection on the Complication (Christie, 2005) and depicts the following events (Martin \& Rose, 2008).

In the light of Thematic progression patterns, the text analysis was done by following the theories of Thematic progression proposed by Eggins (2004) and Bloor and Bloor (2004). In simply, they argued that Theme development can be traced through three patterns: Reiteration pattern, Zig-Zag pattern, and Multiple patterns. Nevertheless, there were only two patterns of Thematic progression applied in the Narrative texts. The most frequent pattern appeared in the texts wasReiteration pattern in which the same Theme wasvaluably repeated to elaborate the characters' behavior or action. The finding was in line with Bloor and Bloor (2004) who said that in story genre Theme constant pattern sometimes used to make focus on the behavior of one person. As can be seen above, the Topical Theme of the three clauses was "she". It means that the topic under discussion refers to "she" or specifically refers to "the real princess". These clauses have focused the message on how the real princess' attitude in the story. Another pattern revealed in the texts is Zig-zag pattern where the Rheme of one clause was promoted as the Theme of the following clause. This pattern supported the cohesion achievement of the text by giving newly information that gave a sense of cumulative development of the text (Eggins, 2004). It made the communication of idea coherent and effectively delivered. Especially in the Narrative, it contributed to the connectedness of one event to another event. Overall, the use of Reiteration and Zig-zag pattern in the Narrative indicated that aside of giving focus on the characters behavior, it is also meant to keep the logical element relation of the text (Fries, 1995; Eggins, 2004; Bloor \& Bloor, 2005). Instead of the findings above this study also investigated that there were some discontinuities in some clauses as for example in the complication stage of the second text below: 
11. One evening a terrible storm came; lightening flashed, thunderedted and the rain poured down in torrents

12. Itwas simply awful

13. Suddenly therewas a knock at the city gate

14. And the old king went out [[to answer it]]

15. There was a princess [[standing outside]]

16. But [[what a sight the rain and the bad weather]] had made her

17. The water streamerown her hair and her clothes

Figure 1. Example of Undefined patterns in text 2

Those happened because some unrelated Topical Themeappeared in this stage. The pattern did not belong to the three of Thematic progression patterns proposed by some experts such as Eggins (2004), and Bloor and Bloor (2004). It could be the reason for the readers to get lost the thread (Butt et al., 2000, p, 152). However, Theme development should be taken into account as a significant aspect in the process of texts' selection for students. As suggested by Butt et al. (2000) suggested that the study of Theme development can help students to discover the "point" of the text and conclude the text's purpose. Moreover, it is very useful for reader because it can guide to note taking and summarizing (Butt et al., p. 155).

The further discussion was dealt with teacher's difficulties found in understanding the structure of the text through the Theme and Thematic progression patterns for Narrative. It is proven by the fact that there were still some discontinuities in some clauses. It should be noticed since the discontinuities found were able to hinder students understanding the text. Moreover, it happens due to the lack of the teacher in understanding the Theme system. Based on the interview, the lack of teacher's understanding about theme system was one of the reasons for difficulties in developing and providing suitable texts material for the students. The teacher confirmed that Theme system grounded from Systemic Functional Linguistics was unfamiliar for him. Therefore, selecting the materials by using Theme system was something new for the teacher. Regarding the difficulties, the study analyzed the teacher's way to overcome them by learning to understand the Theme system including Theme and Thematic progression patterns. By doing so the teacher may get the awareness and exposures related to Theme system which can guide him in developing Narratives. In line with this, teachers' understanding in Theme system will help the teachers implement his knowledge in the pedagogic actions (Jones and Chen, 2012).

\section{CONCLUSIONS}

Regarding to the results of data analysis and discussions from both data- documentation and interview- some points can be concluded. Firstly, the narrative texts composed by the teacher as learning materials showed Theme choices namely Topical Theme, Textual Theme and Interpersonal Theme. While in terms of Thematic Progression patterns, there were two patterns found; the Reiteration pattern and Zig-zagpattern. The use of Reiteration pattern was mostly dominating the patterns of the text development functioning to keep the focus of the text on the characters' action in the story. Whereas, Zigzag pattern for several times were also occupied in the texts to keep the smoothness within unfolding events in the story. Overall, most of the Theme and Thematicprogression patterns revealed in the texts have supported the purpose of each stage. However to develop the texts itself, the teacher still met some difficulties in putting Theme and Thematic progression patterns proven by some undefined patterns found in the texts. This is due to their inadequate knowledge of Theme and Thematic progression patterns that should be put in the texts, particularly in writing Narratives. Therefore, the teacher overcomes those problems through learning to understand those system and patterns well as proposed by Halliday (2004) and Bloor and Bloor (2004) with the Systemic Functional analysis. By doing so, the teacher could get more exposures which can build the language awareness to develop Narratives according to Theme and Thematic progression patterns.

\section{REFERENCES}

Bloor, T., \& Bloor, M. (2004).The functional analysis of English: A Hallidayan approach. London: Arnold

Brown, D. (2001). Teaching by principles: An approach to language pedagogy(2nd ed). New York: Longman

Butt, D., Rhondda, F., Feez, S., Spinks, S., \& Collin, Y. (2000). Using functional grammar.Sydney: Macquarie University.

Caffarel, A., Martin, J. R., \&Matthiessen, C. M. (2004). Language typology: A functional perspective. Amsterdam: John Benjamins.

Christie, F. (2005). Language education in the primary years. Sydney, NSW: UNSW Press.

Christie, F., \& Derewianka, B. (2008). School discourse: Learning to write across the years of schooling.London: Continuum.

Eggins, S. (2004). Intoduction to Systemic Functional Linguistic 2nd.New York: Continuum.

Emilia, E. (2005). A Critical Genre Based Approach to Teaching Academic Writing in a Tertiary EFL Context in Indonesia, Unpublished $\mathrm{PhD}$ Thesis, Department Of Language, Literacy and Arts Education, University of Melbourne

Emilia, E. (2014). Introduction to Functional Grammar.Bandung: Pustaka Jaya. 
Fraenkel, J. R., Wallen, N. E., \& Hyun, H. H. (2012).How to design and evaluate research in education (8th ed). New York, USA: McGraw-Hill.

Gerot, L. (2000). 9 Exploring reading processes. Researching Language inn Schools and Communities: Functional Linguistic Perspectives, 204.

Halliday, M., and Matthiessen, C. (2004).An introduction to functional grammar. UK: Hodder Education

Halliday, M. A. K., and Matthiessen. (2006). Construing experience through meaning. New York: Continuum.

Irene, C \& Kiely, R. (2012). Reading comprehension in test preparation classes: key challenges for TESO.TESOL Quartely. Vol. 49, no.2. 2015

Jing, W. (2016).Theme and thematic rogression in English writing teaching. Singapore: Springer.

Jones, P. T. \& Chen, H. (2012). Teachers' knowledge about language: issues of pedagogy and expertise. Australian Journal of Language and Literacy, $35 \quad$ (2), 147168.

Lock, G. (1996). Functional English grammar: An introduction for second language teachers. Cambridge: Cambridge University Press.

Martin, J. R., \& Rose, D. (2008).Genre relations: Mapping culture.London: Equinox Pub.

Shieh, C., \& Lin, K. S. (2011).Thematic progression patterns and the texts of the department required English test, 15-34.

Thompson, G. (2014). Introduction to functional grammar 4th edt. Canada: Routledge

Wang, L. (2007). Theme and rheme in thematic progression of text: Implication for teaching academic writing. Asian EFL Journal , 164-176. 